\title{
TOKOH AGAMA DALAM PENDIDIKAN TOLERANSI BERAGAMA DI KABUPATEN LUMAJANG
}

\author{
Antik Milatus Zuhriah \\ Institut Agama Islam Syarifuddin Lumajang, Indonesia \\ E-mail: antikmilatuszuhria1996@gmail.com
}

\begin{abstract}
Abstrak: Fenomena keanekaragaman agama, dan etnis merupakan fakta dan realitas yang dihadapi manusia, maka harus ada kesadaran bahwa multikulturalisme dan pluralisme memang sungguh-sungguh fitrah kehidupan manusia. Karenanya, diharapkan manusia mampu menghargai keanekaragaman itu. Dalam perspektif Islam, muncul istilah Pendidikan Islam Pluralis-Multikultural. Konstruksi pendidikan semacam ini berorientasi pada proses penyadaran yang berwawasan pluralitas secara agama, sekaligus berwawasan multikultural. Agar spesifik, artikel ini membahas konsepsi toleransi dalam perspektif Tokoh Agama di Kertosari Kecamatan Pasrujambe Kabupaten Lumajang. Hasil penelitian ini menunjukkan bawah toleransi dan sikap saling menghargai, sikap saling menerima perbedaan harus terus dikembangkan dengan catatan tetap memperhatikan batasan-batasan tertentu. Berikutnya, peran tokoh agama dalam pendidikan toleransi beragama meliputi sangat urgen, selain sebagai pemimpin agama, masyarakat juga menganggap tokoh agama juga sebagai motivator, panutan, penyuluh, pendidik dan bahkan sebagai pembimbing. Hal ini menunjukkan bahwa dalam hal toleransi beragama, tokoh agama yang menjadi pusat rujukan masyarakat.
\end{abstract}

Kata kunci: Tokoh Agama, pendidikan toleransi

\section{Pendahuluan}

Islam adalah agama yang universal artinya rahmatan lil alamin. Umat Islam yang sangat menginginkan hidupnya mendapatkan ridha Allah SW'T selalu berpegang teguh pada ajaran Islam, baik hubungan secara vertikal kepada Allah maupun secara horisontal senantiasa harus dibina. Dalam hal ini manusia bukan hanya harus beribadah pada Allah secara langsung tetapi juga harus membina hubungan bermasyarakat.

Islam sejak awal lahirnya telah menampakkan nilai-nilai humaniora yang kental di masyarakat. Dengan caranya yang santun para Mubaligh Islam saat itu menginfiltrasi budaya dan agama yang saat itu ada dengan ajaran Islam yang tanpa merusak budaya lokal. Dari situlah Islam dikenal bangsa Indonesia sebagai agama yang toleran. Tidak ada penghinaan terhadap agama lain namun tetap wibawa menjaga kehormatannya. Bentuk keseimbangan inilah yang kemudian menjadi dasar diterimanya Islam oleh masyarakat Indonesia.

Berangkat dari kesadaran adanya fenomena keanekaragaman agama, dan etnis yang merupakan fakta dan realitas yang dihadapi manusia saat ini, maka harus ada kesadaran bahwa multikulturalisme dan pluralisme memang sungguh-sungguh fitrah kehidupan manusia. Sehingga diharapkan manusia mampu untuk dapat menghargai keanekaragaman itu. ${ }^{1}$ Oleh karena itu sebagai warga Negara sudah sepatutnya menjunjung tinggi sikap saling toleransi

\footnotetext{
${ }^{1}$ Musahadi, Mediasi Dan Resolusi Konflik di Indonesia (Semarang: Walisongo: Mediation Centre, 2007), 139-14. 
antar umat beragama dan saling menghormati antar hak dan kewajiban yang ada diantara kita demi keutuhan Negara.

Dalam perspektif Islam, tidak dapat dilepaskan dengan konsep pluralitas, sehingga muncul istilah Pendidikan Islam Pluralis-Multikultural. Konstruksi pendidikan semacam ini berorientasi pada proses penyadaran yang berwawasan pluralitas secara agama, sekaligus berwawasan multikultural. Dalam kerangka yang lebih jauh, konstruksi pendidikan Islam pluralismultikultural dapat diposisikan sebagai bagian dari upaya secara komprehensif dan sistematis untuk mencegah dan menanggulangi konflik etnis agama, radikalisme agama, separatisme, dan integrasi bangsa. Nilai dasar dari konsep pendidikan ini adalah toleransi. ${ }^{2}$

Bersikap toleran merupakan solusi agar tidak terjadi perpecahan dalam mengamalkan agama. Sikap bertoleransi harus menjadi suatu kesadaran pribadi yang selalu dibiasakan dalam wujud interaksi sosial. Toleransi dalam kehidupan beragama menjadi sangat mutlak adanya dengan eksisnya berbagai agama samawi maupun agama ardli dalam kehidupan umat manusia ini. Dalam kaitanya ini Allah telah mengingatkan kepada umat manusia dalam firmannya: ${ }^{3}$

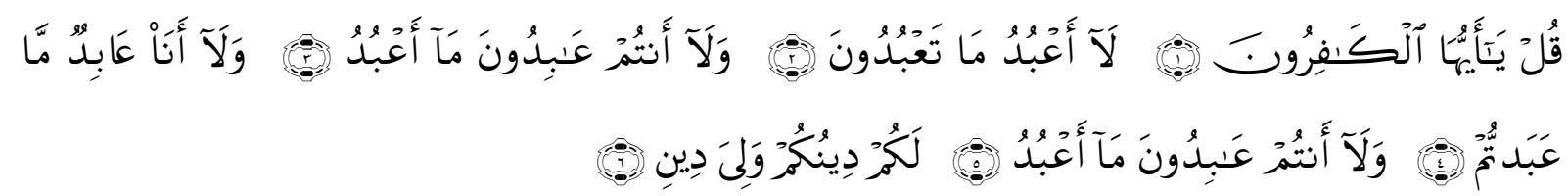

Artinya: Katakanlah: (1) Hai orang-orang kafir; (2 )aku tidak akan menyembah apa yang kamu sembab; (3) dan kamu bukan penyembah Tuban yang aku sembab: (4) dan aku tidak pernab menjadi penyembah apa yang kamu sembah; (5) dan kamu tidak pernah (pula) menjadi penyembab Tuban yang aku sembah: (6) untukmu agamamu, dan untukkulah, agamaku.

Pada Ayat tersebut, Islam menjunjung tinggi perbedaan di mana masing-masing saling menghargai perbedaan dan menyilakan masing-masing untuk beribadah sesuai keyakinannya. Oleh sebab itu kita sebagai warga Negara sudah sepatutnya menjunjung tinggi sikap saling toleransi antar umat beragama dan saling menghormati antar hak dan kewajiban yang ada diantara kita demi keutuhan Negara.

Berdasarkan ketentuan dilandaskan dalam Undang-Undang Dasar 1945 Pasal 29 tentang Agama disebutkan bahwa (1) Negara berdasarkan atas Ketuhanan yang maha Esa (2) Negara menjamin kemerdekaan tiap-tiap penduduk untuk memeluk agamanya masing-masing dan untuk beribadat menurut agamanya dan kepercayaannya itu. Negara juga menjamin kebebasan beragama dan beribadah bagi setiap warga negara dengan mengeluarkan aturan regulasi untuk menata dan menjaga relasi antarumat beragama agar toleran, rukun dan harmonis. ${ }^{4}$

\footnotetext{
${ }^{2}$ Ngainun Naim dan Achmad Sauqi, Pendidikan Multikultural: Konsep dan Aplikasi (Yogyakarta: Ar-Ruzz Media, 2008)

3 Al-Qur'ān, 109: 1-6.

${ }^{4}$ UUD 1945 Pasal 29 ayat 1 dan 2
} 
Untuk itu penilaian atas toleransi sejatinya didasarkan pada sikap hormat terhadap martabat setiap manusia, hati nurani serta keyakinan dan keikhlasan bersama. Mereka bersedia bertukar pikiran atau berdialog dengan sikap terbuka untuk mencari pengertian, toleran dalam arti positif. Toleransi juga berarti sabar, lapang dada, sedia memahami orang lain dengan tidak ingin saling mengganggu antara satu dengan yang lain. ${ }^{5}$

Setelah memahami uraian tentang pentingnya kedamaian serta kerukunan dalam interaksi antar umat beragama tidak jarang kita melihat realitas konflik yang disebabkan antar pemeluk agama baik dalam satu wilayah, desa atau kota bahkan dalam ruang lingkup Negara. Potensi konflik antar umat beragama maupun etnis masih sangat rawan terjadi. Berdasarkan kenyataan itu, maka peran tokoh agama sangat dibutuhkan dalam pendidikan toleransi tersebut untuk membangun kerukunan dan keselarasan sebagai mahluk sosial yang hidup berdampingan. Tokoh agama menjadi ujung tombak dalam membina kerukunan antar umat beragama, sehingga tokoh agama harus memiliki kemampuan untuk mencermati persoalan yang muncul dalam masyarakat.

Beberapa tahun terakhir ini banyak wilayah di Indonesia muncul berbagai kerusuhan social berlatar belakang permasalahan suku, agama, ras dan antar golongan (SARA), yang sangat potensial mengancaam integrasi bangsa. Kehidupan masyarakat yang semula berjalan rukun daan harmonis, kini porak poranda akibat kerusuhan tersebut yang menelaah korban harta dan jiwa yang tak terbilang jumlahnya. Dinegara kita, perah terjadi serentetan kerusuhan yang berbau SARA (suku, Agama, Ras, dan Antar golongan), misalnya saja yang yang pernah terjadi di Banyuwangi, Sampit, Sambas, Maluku, Poso, Tasikmalaya, Kupang, Sampang, dan sebagainya yang hingga saat ini kadang-kadang juga muncul berbagai isu yang berkembang tentang sebab terjadinya huru-hara tersebut sangat variatif misalnya mulai perebutan jabatan di pemerintahan, perebutan wilayah yang potensial dan adanya polarisasi social-ekonomi. ${ }^{6}$

Dari sekian banyak isu yag berkembang penyebab terjadinya kerusuhan, faktor agama nampaknya lebih banyak dibanding dengan isu lainnya. Hal ini dibuktikan dengan adanya penggunaan retorika-retorika dan symbol-simbol keagamaan sebagai pemicu emosi pihak yang terlibat konflik, termasuk juga sasaran penyerangan ditunjukkan pada lawan agamanya berikut fasilitas peribadatannya. Hal ini tentunya sangat memprihatinkan karena dialog antar umat

\footnotetext{
${ }^{5}$ Zainuddin, Pluralisme Agama dalam Analisis Konstruksi Sosial: Pergulatan Dialogis Islam-Kristen di Indonesia (Malang: UINMaliki Press, 2013), 66

6 Muhammad Syamsudini, "Konsep Kerukunan Multikultural Kabupaten Banyuwangi", Jurnal Penelitian Islam Indonesia: Fenomena, Vol.7. No.1, Maret 2008, 59. 
beragama, khususnya di Indonesia, sangat intens dilakukan berbagai kalangan dalam rangka menumbuhkan saling pengertian, toleransi dan kedamaian diantara agama yang berbeda. ${ }^{7}$

Ada hal yang menarik yang mungkin tidak dimiliki oleh desa-desa yang lain yaitu Desa Kertosari Kecamatan Pasrujambe Lumajang. Desa ini memiliki ragam etnis dan agama. Agama yang berkembang dan dianut oleh sebagian besar masyarakat desa adalah Islam dan Hindu. Faktanya, umat yang beragam tersebut hidup berdampingan dan membaur dengan pemeluk agama lain serta dapat bekerjasama dalam aktivitas sosial dan menciptakan suasana yang kondusif. Masyarakat tersebut memeluk agama atau kepercayaan yang berbeda-beda, namun perbedaan kepercayaan tersebut tidak menjadi penghalang untuk hidup berdampingan dengan masyarakat lain yang berbeda keyakinan. Dalam kesehariananya masyarakat di Desa kertosari selalu hidup rukun dan menjunjung tinggi toleransi antara umat beragama.

Berdasarkan cara pandang di atas, artikel ini hendak melihat apa dan bagaimana desa yang multi agama dan etnis dapat menjaga toleransi dengan cukup baik.

\section{Gambaran Desa}

Secara Geografis, Desa Kertosari menurut data dari alat ukur GPS berada pada

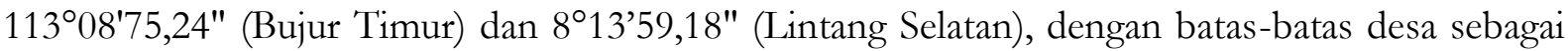
berikut:

1. Sebelah Utara : Desa Sukorejo/Jambearum/Pagowan

2. Sebelah Timur : Desa Tumpeng/Karanganom

3. Sebelah Selatan : Desa Kloposawit

4. Sebelah Barat : Desa Pasrujambe/Jambearum

Jarak dari Desa ke ibukota Kecamatan, Kabupaten dan Provinsi dapat dirinci sebagai berikut: 1) Desa Kertosari - Ibukota Kecamatan : 3 km: 2) Desa Kertosari - Ibukota Kabupaten $17 \mathrm{~km}$ 3) Desa Kertosari - Ibukota Provinsi ; $157 \mathrm{~km} .{ }^{8}$. Mata pencaharian masyarakat Desa Kertosari yang utama adalah disektor pertanian.

Jumlah penduduk Desa Kertosari sebanyak 3.473 jiwa yang terbagi dalam 1.029 Rumah Tangga. Dengan luas wilayah sebesar $6,66 \mathrm{~km} 2$ maka kepadatan penduduk rata2 sebesar 521 jiwa $/ \mathrm{km} 2$ dengan rata-rata 3 orang dalam anggota rumah tangga. Dalam hal keagamaan, mayoritas penduduk Kecamatan Pasrujambe beragama Islam dan pemeluk agama moyoritas kedua adalah Hindu, dengan rincian sebagai berikut:

${ }^{7}$ Syamsun Ni'am, "Potret Persaudaraan Umat Beragama Melacak Tradisi Keberagaman Demi Terwujudnya Kerukunan Umat Beragama di Desa Tanon, Kecamatan Papar Kabupaten Kediri”, Jurnal Penelitian Indonesia: Fenomene, Vol.7. No.1, Maret 2008, 80.

8 http:/ / kertosari-pasrujambe.lumajangkab.go.id/index.php/ first/katagori/40 
Tabel Jumlah Umat Beragama di Kecamatan Pasrujambe

\begin{tabular}{|c|l|r|r|r|r|r|r|}
\hline No & $\begin{array}{c}\text { Desa/ } \\
\text { Kelurahan }\end{array}$ & Islam & Kristen & Katholik & Hindu & Buda & Konghucu \\
\hline 1 & Pasrujambe & 9681 & 7 & 0 & 8 & 0 & 0 \\
\hline 2 & Jambekumbu & 5010 & 0 & 0 & 26 & 0 & 0 \\
\hline 3 & Sukorejo & 3065 & 0 & 0 & 6 & 0 & 0 \\
\hline 4 & Jambearum & 3575 & 2 & 0 & 40 & 0 & 0 \\
\hline 5 & Kertosari & 3240 & 0 & 0 & 325 & 0 & 0 \\
\hline 6 & Pagowan & 3009 & 0 & 0 & 49 & 0 & 0 \\
\hline 7 & Karanganom & 5966 & 0 & 0 & 0 & 5 & 0 \\
\hline
\end{tabular}

Sumber Data: Dokumentasi dari Website Desa Kertosari

Dengan jumlah umat Hindu 325 jiwa di Desa Kertosari tersebut, mayorias penduduk umat hindu menetap di Dusun Dadapan, yaitu Desa yang berada di sebelah Utara di Desa Kertosari. Di Dusun Dadapan inilah terdapat $140 \mathrm{KK}$ yang beragama Islam dan $40 \mathrm{KK}$ yang beragama Hindu.

Masyarakat Dusun Dadapan adalah masyarakat yang majemuk karena terdapat dua agama yang dianut oleh masyarakat yaitu agama Islam dan Hindu. Dengan berkembangnya dua agama maka akan mempengaruhi interaksi dan hubungan sosial antar pemeluk agama.

Dalam kehidupannya yang harmonis tidak lepas dari ketersediaan tempat dan waktu untuk umat beragama melaksanakan ibadah sesuai dengan keyakinannya secara aman. Tempat ibadah yang terdapat di Dusun Dadapan Desa Kertosari Kecamatan Pasrujambe yaitu terdapat satu Masjid dan 3 Musholla untuk umat Islam dan 2 Sanggar untuk umat Hindu. Untuk lebih jelasnya dapat dilihat dalam tabel berikut:

Sarana Prasarana Ibadah di Desa Kertosari

\begin{tabular}{|l|l|c|}
\hline No & \multicolumn{1}{|c|}{ Jenis Tempat Ibadah } & Jumlah \\
\hline 1 & Masjid Baiturrohim & 1 \\
\hline 2 & Musholla Daarussalam & 1 \\
\hline 3 & Musholla Roudlotul Musthofa & 1 \\
\hline 4 & Musholla Al-Firdaus & 1 \\
\hline 5 & Sanggar di Dadapan Jambearum & 1 \\
\hline 6 & Sanggar di Dadapan Kertosari & \\
\hline
\end{tabular}

Sumber Data: Dokumentasi dari Perangkat Desa

\section{Pendidikan Toleransi Beragama dan Dinamikanya}

Toleransi berasal dari bahasa latin, "Tolerar" yang berarti menahan diri, bersikap sabar, menghargai orang lain berpendapat lain, berhati lapang dan tenggang rasa terhadap orang yang

\footnotetext{
${ }^{9}$ http://kertosari-pasrujambe.lumajangkab.go.id/index.php/ first/katagori/40

60 | Tarbiyatuna: Jurnal Pendidikan Islam; Volume 13, Nomor 1, Februari 2020 
berlainan pandangan atau agama. Dalam Kamus Besar Bahasa Indonesia diterangkan bahwa toleransi adalah bersifat atau bersikap menenggang (menghargai, membiarkan, membolehkan) pendirian (pendapat, pandangan, kepercayaan, kebiasaan, kelakuan) yang berbeda atau bertentangan dengan pendiriannya sendiri. ${ }^{10}$

Toleransi dalam agama Islam disebut juga dengan tasamuh. Sikap tasamuh atau toleransi adalah sikap saling menghormati perbedaan yang ada, apakah dalam hal kepercayaan akidah, atau juga ritual peribadatan, serta perbedaan pandangan dan pendapat yang berbeda, terlebih cerminan umat yang terbentuk sebelum Islam bukan saja terdiri dari kaum muslimin, tetapi juga ada mereka yang memeluk agama Yahudi dan Nasrani. ${ }^{11}$

Konsepsi para Tokoh agama di Desa Kertosari Dsn Dadapan dalam memaknai pendidikan Toleransi beragama ialah sikap saling menghargai, sikap saling menerima perbedaan dengan memperhatikan batasan-batasan tertentu. Dalam artian tanpa mengorbankan prinsipprinsip yang terdapat dalam ajaran agama yang dianutnya.

Toleransi atau Tasamuh berisi tindakan tuntutan dan penerimaan dalam batas-batas tertentu. Pelaku tasamuh atau Mutasamihin yaitu masyarakat Desa Kertosari mengatakan bahwa dalam pelaksanaannya sepatutnya menerima saja sehingga menekan batasan hak dan kewajibannya sendiri. Dengan artian perilaku tasamuh dalam beragama memiliki pengertian untuk tidak saling melanggar batasan, terutama yang berkaitan dengan batasan keimanan (Aqidah). AlQur'an tidak pernah menyebut-nyebut kata tasamuh atau toleransi secara tersurat dalam ayatayatnya. Namun secara eksplisit Al-Qur'an dan hadist Rasulullah SAW telah menjelaskan konsep toleransi dengan segala batasan-batasannya.

Sebagai pembeda dengan sikap tasamuh, terdapat tiga nilai Aswaja sikap yang selalu diajarkan oleh Rasulullah S.A.W dan para sahabatnya. Yaitu: ${ }^{12}$ At-Tawassuth (sikap tengahtengah, sedang-sedang, tidak ekstrimkiri ataupun ektrim kanan). At-Tawazun, (seimbang dalam segala hal, termasuk dalam penggunaan dalil 'aqli dan dalil naqli). Al-I'tidal (tegak lurus dan membela kebenaran). Sedangkan Tasamuh (toleransi) ialah sikap menghargai perbedaan serta menghormati orang yang memiliki prinsip hidup yang tidak sombong. Namun bukan berarti mengakui atau membenarkan keyakinan tersebut dalam meneguhkan apa yang diyakini.

Dalam realitasnya manusia tidak dapat hidup tanpa orang lain, itu sebabnya manusia disebut makhluk sosial yang saling membutuhkan satu sama lain. Dalam kehidupan masyarakat

\footnotetext{
${ }^{10}$ Umar Hasyim, Toleransi dan Kemerdekaan Beragama dalam Islam sebagai Dasar Menuju Dialog dan Kerukunan Antaragama (Surabaya: PT. Bina Ilmu, 1979), 22.

${ }^{11}$ Darwyan Syah, "Pemahaman Surat-Surat Pendek Alquran tentang Toleransi dan Implikasinya Bagi Pengembangan Sikap Pluralisme" Analisis, Volume XIII, Nomor 2, Desemberi 2013, 321.

${ }^{12}$ Muhyiddin Abdusshomad, Hujjah NU Aqidah, Amaliah, Tradisi (Surabaya: Kahlista, 2015), 7-8
} 
yang kompleks tentunya dibutuhkan rasa toleransi. Hukum toleransi antarumat dalam pluralitas agama adalah sebagai berikut: ${ }^{13}$

1. Kufur, bilamana rela serta meyakini kebenaran aqidah agama lain

2. Haram, bila ada kerelaan pembenaran terhadap perilaku kemaksiatan

3. Sunnah, bilamana terbangun kerukunan, kemanfaatan serta kemaslahatan

Dalam melaksanakan toleransi beragama kita harus mempunyai sikap atau prinsip untuk mencapai kebahagiaan dan ketenteraman. Adapun prinsip tersebut adalah: a) Kebebasan Beragama; ${ }^{14}$ b) Penghormatan dan Eksistensi Agama lain; ${ }^{15}$ c) Agree in Disagreement (setuju di dalam perbedaan) ${ }^{16}$

Prinsip pendidikan toleransi dalam masyarakat Desa Kertosari jika dikaitkan dengan nilai kandungan ayat Lakum Dinukum Waliadin. ${ }^{17}$ Prinsip tersebut mengajarkan kepada masyarakat bahwa dalam hubungan keagamaan tidak saling memaksakan antara keyakinan yang satu dengan keyakinan yang lain, tidak seperti hal nya yang dilakukan kaum Quraisy terhadap Islam. Melainkan benar-benar menyerahkan urusan keyakinan beragama kepada tiap-tiap individu.

Disamping prinsip-prinsip tersebut, juga terdapat prinsip menghargai eksistensi antarumat beragama hal ini menjadi sangat penting bagi masyarakat Desa Kertosari. menghargai eksistensi atau keberadaan orang lain meski ditengah perbedaan keyakinan merupakan bukti bahwa mereka dapat menciptakan salah satu sikap yang mampu menciptakan toleransi di masyarakat. Hal ini ditunjukkan dengan cara mereka saling sillaturrahim dan berinteraksi dalam kegiatan keagaamaan, sosial dan ekonomi.

Prinsip-prinsip tersebut telah menjadi simbol di Desa Kertosari bahwa masyarakat antarumat beragama selalu menjunjung nilai-nilai pendidikan toleransi dengan memantapkan kepercayaan dan meyakinkan kebenaran agama yang dipeluknya dengan menyadari bahwa ada keyakinan lain yang diimani oleh pemeluk agama lain. Meskipun dalam implementasi prinsipprinsip tersebut masih butuh dukungan dan bimbingan supaya masyarakat Desa Kertosari Dsn Dadapan lebih memperhatikan dalam menjalankan batasan-batasan toleransi agar tidak keblablasan dalam takaran akidahnya.

\footnotetext{
${ }^{13}$ Yassir Arafat, Fiqih Galak Gampil Menggali Dasar Tradisi Keagamaan Muslim Ala Indonesia (Pasuruan: Ngalah Desing, 2008), 106.

${ }^{14}$ Abd. Al Mu'tal As Saidi, Kebebasan Berfikir dalam Islam (Yogyakarta: Adi Wacana, 1999), 4.

${ }^{15}$ Ruslani, Masyarakat Dialoq Antar Agama, Studi atas Pemikiran Mubammad Arkoun (Yogyakarta:Yayasan Bintang Budaya, 2000), 169.

${ }^{16}$ Faisal Ismail, Islam Yang Produktif (Yogyakarta: IRCiSoD, 2017), 30.

17 Al-Qurân, 109:6

62 | Tarbiyatuna: Jurnal Pendidikan Islam; Volume 13, Nomor 1, Februari 2020 p-ISSN: 2085-6539; e-ISSN: 2242-4579
} 
Dalam Islam toleransi bukanlah fatamorgana atau bersifat semu. Tapi memiliki dasar yang kuat dan tempat yang utama. Ada beberapa ayat di dalam Al-Qur'an yang bermuatan pendidikan toleransi diantaranya:

Toleransi Perspektif Al-Qur'an

\begin{tabular}{|c|c|c|c|}
\hline No & Surah dan Ayat & $\begin{array}{c}\text { Isi } \\
\text { Kandungan }\end{array}$ & Pendidikan Toleransi \\
\hline 1 & $\begin{array}{l}\text { Al-Kâfirûn (109) } \\
: 1-6 \\
\text { Al-Imrân (3) : } 19\end{array}$ & $\begin{array}{l}\text { Batasan } \\
\text { toleransi } \\
\text { terhadap } \\
\text { keyakinan dan } \\
\text { peribadahan }\end{array}$ & $\begin{array}{l}\text { - Batasan ini menjadi pedoman pertama } \\
\text { dalam toleransi beragama supaya umat } \\
\text { beragama dapat mengetahui posisinya } \\
\text { maisng-masing ketika menghadapi } \\
\text { berinteraksi dengan umat agama lain } \\
\text { - Toleransi ditegakkan diatas timbangan } \\
\text { syariah Islamiyah sehingga tidak } \\
\text { keblabasan }\end{array}$ \\
\hline 2 & $\begin{array}{l}\text { Yûnûs (10) : } 99 \\
\text { Al-Bâqârâh (2): } \\
256 \\
\text { An-Nâjm (53) : } \\
23 \\
\text { Al-Ghâsyiyâh } \\
\text { (88) : 21-22 }\end{array}$ & $\begin{array}{l}\text { Tidak ada } \\
\text { paksaan } \\
\text { dalam } \\
\text { beragama }\end{array}$ & $\begin{array}{l}\text { - Setiap umat beragama diberikan } \\
\text { kebebasan untuk menentukan } \\
\text { keyakinan yang akan dianutnya } \\
\text { - Tidak memaksa orang lain untuk } \\
\text { menganut agama yang dianutnya } \\
\text { - Menolak sinkretisme tanpa } \\
\text { mengorbankan prinsip sendiri }\end{array}$ \\
\hline 3 & $\begin{array}{l}\text { Al-Bâqârâh (2) : } \\
190 \\
\text { Al-Hûjûrât (49) : } \\
13\end{array}$ & $\begin{array}{l}\text { Larangan } \\
\text { mendhalimi } \\
\text { antarumat } \\
\text { beragama }\end{array}$ & $\begin{array}{l}\text { - Toleransi berbuat baik tanpa memusuhi } \\
\text { agama lain } \\
\text { - Hidup berdampingan dengan umat } \\
\text { yang berbeda agama dengan rukun } \\
\text { - Islam memperbolehkan hidup } \\
\text { bermasyarakat dan bernegara selama } \\
\text { tidak melanggar prinsip-prinsip } \\
\text { terpenting dalam Islam }\end{array}$ \\
\hline 4 & $\begin{array}{l}\text { Al-Mâidâh (5) : } \\
\text { Al-Mûmtâhânâh } \\
(60): 8-9 \\
\text { An-Nâhl (16) : } \\
125 \\
\text { Al- An'âm (6) : } \\
108 \\
\text { Al-Ankâbûût } \\
\text { (29): } 46\end{array}$ & $\begin{array}{l}\text { Berbuat adil } \\
\text { dan berbuat } \\
\text { baik } \\
\text { antarumat } \\
\text { beragama }\end{array}$ & $\begin{array}{l}\text { - Toleransi antarumat beragama dengan } \\
\text { cara berbuat adil, dan berbuat baik } \\
\text { dengan cara saling menolong } \\
\text { - Menekankan pentingnya keadilan dan } \\
\text { kasih sayang yang semuanya merupakan } \\
\text { pilar-pilar tolerannsi } \\
\text { - Berdialog dengan baik antarumat } \\
\text { beragama dengan menghindari dirinya } \\
\text { sebagai orang yang paling benar }\end{array}$ \\
\hline
\end{tabular}


Selain ayat tersebut, Allah juga berfirman dalam QS. An-Najm; 23 yang merintah umat Islam untuk membebaskan diri dari mengikuti orang orang kafir dalam semua hal yang ada pada mereka, karena seorang penyembah harus memiliki sembahan yang ia sembah dengan cara-cara tertentu.

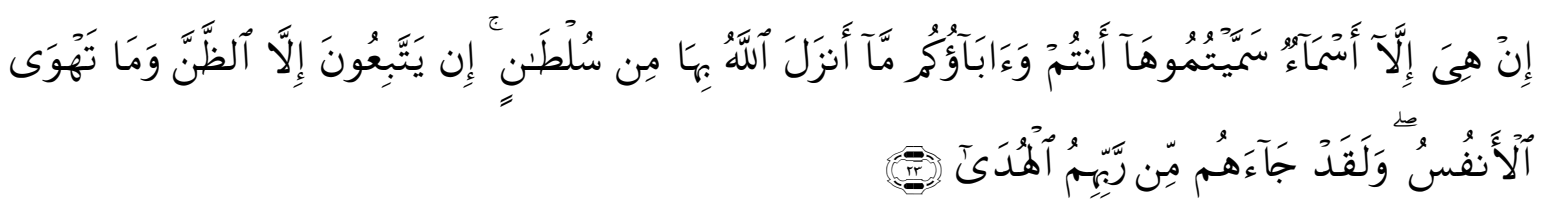

Artinya: Itu tidak lain hanyalah Nama-nama yang kamu dan bapak-bapak kamu mengadakannya; Allah tidak menurunkan suatu keteranganpun untuk. (menyembah) nya. mereka tidak lain hanyalah mengikuti sangkaan-sangkaan, dan apa yang diingini oleh hawa nafsu mereka dan Sesunggubnya telah datang petunjuk kepada mereka dari Tuban mereka. ${ }^{18}$

Dalam kehidupannya masyarakat Desa Kertosari saling mengakui bahwa perbedaan merupakan rahmatal lil 'alamin bagi mereka karena mereka meyakini bahwa disamping perbedaan masih banyak terdapat persamaan-persamaan diantara satu agama dengan agama yang lain. Berdasarkan pengertian inilah hormat-menghormati dan saling menghargai harus ditumbuhkan dalam pribadi setiap umat beragama. Dari sini dapat dirasakan oleh masyarakat Desa kertosari bahwasanya dengan sendirinya timbul sikap saling menghargai diantara pemeluk agama yang satu dengan yang lainnya, yang akibatnya dapat menciptakan kerukunan dan keharmonisan dalam kehidupan. Dengan begitu hubungan diantara mereka menumbuhkan persaudaran sejati dan saling bermurah hati.

Bentuk toleransi yang dilakukan oleh masyarakat Desa Kertosari Dusun Dadapan dapat dilihat dari berbagai kegiatan yang dilakukan yaitu: a) Kegiatan Keagaamaan yang meliputi: Ibadah Umat, Pengajian Rutin ibu-ibu, Yasinan, Tahlilan, Perayaan Hari Raya, Hadrah Albanjari, TPQ (Taman Pendidikan Al-Quran), Khotmil Al-Quran, Forum Diskusi Umat Islam, dan Persamuan; b) Kegiatan Sosial. Kegiatan tersebut meliputi: Peringatan HUT RI, Slametan Desa, Gotong Royong, Santunan Anak Yatim, Posyandu, Takziah, Menjenguk tetangga yang terkena musibah dan Musdus (Musyawarah Desa); c) Kegiatan Ekonomi, Kegiatan ini meliputi: kegiatan Jual Beli dan Membuka Lapangan Pekerjaan

Dalam kegiatan tersebut, dapat diketahui bahwa pola sikap toleransi yang telah ditanamkan oleh masyarakat Desa Kertosari diantaranya: 1)Saling membantu antara umat beragama dalam melakukan kegiatan keagamaan; 2) Tolong menolong antarumat beragama:3) Mengakui hak setiap orang dan Saling mengerti; 4) Menjaga keamanan dan ketenangan 5), Memenuhi undangan dari agama lain; 6) Menjenguk bila tetangga mendapat musibah; 7) Datang ketika ada kegiatan kemasyarakatan; 8) Menghormati tetangga beda agama yang sedang beribadah; 
8) Menerima bantuan tetangga beda agama; 9)Tidak menghina tetangga beda agama; 10) Memelihara hubungan persaudaraan; 11) Memupuk rasa persatuan dan kesatuan walaupun beda agama; 12) Memelihara kebersamaan

Hal ini dapat digambarkan olehi umat beragama Di Desa Kertosari menjelang perayaan hari Raya akan tiba, masyarakat berbondong-bondong untuk membagikan hidangan berupa nasi dan kue sebagai bentuk rasa syukur atas kesempatan yang dikaruniakan dan bentuk solidaritas dalam menjalin hubungan persaudaraan, yang menjadi menarik dikalangan masyarakat beragama ini ialah karena mayoritas umat Islam yang paling banyak jadi ketika umat Hindu yang merayakan Hari raya akan menjadi tugas yang sangat berat karena umat hindu ini akan membagikan hidangan tersebut keseluruh umat Islam yang berada di Dusun Dadapan tersebut. Namun kondisi seperti tidak menajdi masalah bagi mereka karena umat islam juga membantu dalam mempersiapkannya. Kebersamaan inilah yang akan mempersempit atau bahkan meniadakan perasaan saling curiga. masing-masing individu harus memiliki kesadaran untuk mau memberi dan mau menerima yang tentunya disesuaiakan dengan koridor atau batasan-batasan dalam pergaulan.

Selain itu, yang menjadi pedoman dalam bertoleransi oleh masyarakat Desa kertosari ialah aturan tentang batasan-batasan dalam bertoleransi antar umat beragama bagi umat Islam. Sebagaimana firman Allah SWT dalam Q.S Al-Mumtahanah: 8-9. Dalam ayat tersebut Allah memberi peringatan kepada umat Islam bahwa toleransi itu ada batasannya. Toleransi antar umat beragama tidak boleh dilaksanakan dengan kaum atau golongan yang memusuhi umat Islam karena agama dan mengusir orang-orang Islam dari kampung halamannya, kalau yang terjadi demikian maka umat Islam dilarang untuk bersahabat dengan golongan tersebut. ${ }^{19}$ Bahkan dalam situasi dan kondisi yang demikian itu, Allah memerintahkan dan mewajibkan kepada umat Islam untuk berjihad dengan jiwa, raga dan harta bendanya untuk membela agamanya. Penjelasan tersebut juga terdapat dalam QS. Al-Baqarah: 190.

Dalam penjelasan tersebut jika dikaitkan dengan masyarakat umat Hindu yang terdapat di Desa Kertosari maka batasan toleransi boleh dilakukan antarumat beragama karena Umat di Desa Dadapan mau berdamai dengan umat Islam. Di samping itu Allah juga memberikan batasan toleransi itu hanya sebatas pada kepentingan sosial atau kepentingan duniawi saja, tidak boleh menyangkut pautkan dengan masalah aqidah agama, hal ini dijelaskan dalam fiman Allah surat Al-Kafirun ayat 1-6 : isi kandungan ayat tersebut menjelaskan bahwa kompromi 
agama tidak mungkin dilakukan umat Islam, biarlah dalam hal ibadah ini masing-masing melaksanakan sesuai dengan keyakinannya. ${ }^{20}$

Kegiatan Tahlilan yang sudah menjadi kegiatan di Desa Kertosari Dusun Dadapan telah menjadi kegiatan keagamaan ketika terdapat warga yang meninggal hal ini menjadi pertentangan Tokoh Agama yang melarang acara tersebut, Ustadz Amrullah dalam relasi kegiatan semacam ini menganggap bahwa yang seperti tidak dibenarkan dalam ajaran Islam. Namun jika selaku Tokoh Agama menjelaskan kepada mereka tentang larangan tersebut maka masyarakat tidak akan menerima pendapat tersebut bahkan akan terjadi konflik perbedaan pendapat dikalangan antarumat beragama karena ditinjau dari kalangan masyarakat yang masih awam akan pengetahuan tentang akidah. Maka Ustd. Amrullah menganggap bahwa dalam kegiatan tersebut sebatas kepentingan sosial yang tidak ada kaitannya dengan akidah kita selaku umat Islam. Pendapat ini juga dapat dikaitan dengan adanya pengesahan yang diperbolehkan hidup berdampingan dengan aman dalam kaidah fiqhiyah yaitu : درء المفاسد مقدم على جلب المصاح

\section{Tokoh Agama dan Penjaga Nilai Toleransi}

Dalam Kamus Besar Bahasa Indonesia, Tokoh diartikan sebagai orang yang terkemuka dan terkenal, panutan. Menurut Surbakti bahwa tokoh agama ialah seseorang yang disegani dan dihormati secara luas oleh masyarakat dan dapat menjadi faktor yang menyatukan suatu bangsanegara. $^{21}$

Tokoh agama merupakan ilmuan agama di dalamnya termasuk nama-nama kyai, ulama, ataupun cendekiawan muslim dalam kesehariannya memiliki pengaruh karena adanya kepemimpinan yang melekat pada dirinya. Status tokoh agama mencakup empat komponen: pengetahuan, kekuatan spiritual, keturunan (baik spiritual maupun biologis), dan moralitas. ${ }^{22}$ Tokoh agama adalah orang yang tidak mendapatkan pengangkatan formal sebagai pemimpin, namun karena ia memiliki sejumlah kualitas unggul, dia mencapai kedudukan sebagai orang yang mampu mempengaruhi kondisi psikis dan perilaku suatu kelompok atau masyarakat. ${ }^{23}$

Tokoh agama tentunya merupakan representasi dari adanya sifat-sifat kepemimpinan yang menjadi acuan bagi masyarakat dalam mewujudkan harapan serta keinginan-keinginan masyarakat sehingga tokoh masyarakat, tidak bisa dilepaskan dari sifat kepemimpinan yang tercermin didalam

\footnotetext{
20 Al-Qurân, 109:1-6.

${ }^{21}$ Ramlan Surbakti, Memahami Ilmu Politik (Jakarta:PT.Grasindo,1992), 15.

22 Ronald, Tokoh Agama Dalam Masyarakat (Jakarta : Rineka Cipta, 2004), 23.

${ }^{23}$ Kartini Kartono, Pemimpin Dan Kepemimpinan, Apakah Pemimpin Abnormal Itu? Edisi baru (Jakarta: Raja Grafindo Persada, 1998), 10. 
diri tokoh agama tersebut. Dengan demikian, warga masyarakat mengidentifikasikan diri kepada sang pemimpin, dan ia dianggap sebagai penyambung lidah masyarakat. ${ }^{24}$

Menurut Kartini Kartono dalam kutipannya bahwa Ordway Tead dalam bukunya menuliskan sepuluh sifat pemimpin yang unggul yaitu: a) Energi jasmaniah dan mental; b) Keramahan dan kecintaan (Friendliness and affection); c) Integritas (Integrity, keutuhan, kejujuran, dan ketulusan hati); d) Ketegasan dalam pengambilan keputusan (Decisivines) e) Kecerdasan (Intelligence); f)Kepercayaan (Faith) ${ }^{25}$

Salah satu sifat dari kepemimpinan ialah harus melakukan pengawasan terhadap jamaahnya, meluruskan kekeliruan, dan serta mengajak mereka untuk berbuat kebaikan dan mencegah kemungkaran. Hal ini telah dijelaskan dalam firman Allah: ${ }^{26}$

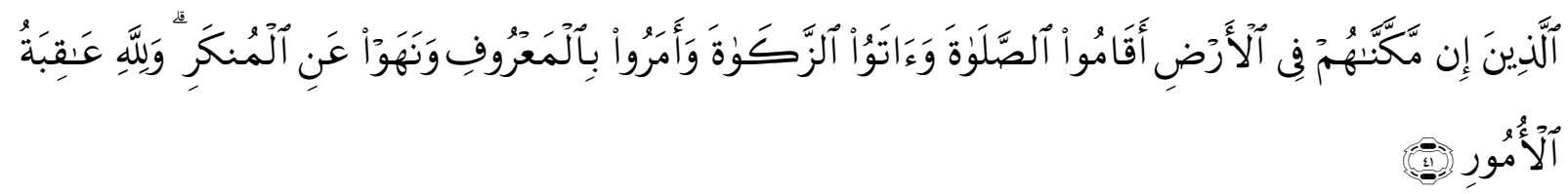

Artinya: orang-orang yang jikea Kami tegubkan kedudukan mereka di muka bumi niscaya mereka mendirikan sembabyang, menunaikan zakat, menyurub berbuat ma'ruf dan mencegah dari perbuatan yang mungkar; dan kepada Allah-lah kembali segala urusan. (QS. Al-Hajj: 41)

Berdasarkan uraian tersebut tokoh agama adalah orang yang tidak mendapatkan pengangkatan formal sebagai pemimpin, namun karena ia memiliki sejumlah kualitas unggul, dia mencapai kedudukan sebagai orang yang mampu mempengaruhi kondisi psikis dan perilaku suatu kelompok atau masyarakat.

Rasulullah SAW juga mengajarkan bahwa sifat-sifat yang dapat dijadikan landasan bagi pemimpin dalam melaksanakan tugasnya dapat dilihat pada sifat-sifat akhlak nabi yaitu: ${ }^{27}$ 1) Sifat kejujuran (Shiddiq); 2) Sifat Tanggungjawab (Amanah); 3) Sifat Komunikatif (Tabligh); 4) Sikap Cerdas (Fathonah); 5) Bersikap positif dan bersikap positif (Khusnudzon); 6) Memperbanyak Sillaturrahim; 7) Disiplin waktu dan menepati janji; 8) Rabbani. 9) Memahami jamaah; 10) Sejuk dan berwibawa. Sifat-sifat ini menggambarkan keadaan tingkah laku yang ada pada setiap tokoh agama. keadaan tingkah laku yang dimunculkan menjadi contoh bagi masyarakat.

Menurut Kartini Kartono dalam kutipannya bahwa Ordway Tead dalam bukunya menuliskan sepuluh sifat pemimpin yang unggul yaitu:

1. Energi jasmaniah dan mental

2. Keramahan dan kecintaan (Friendliness and affection)

3. Integritas (Integrity, keutuhan, kejujuran, dan ketulusan hati)

${ }^{24}$ Julius Sanjaya, Ciri-Ciri Pemimpin Yang Berprinsip: Principle Centered Leadership (Jakarta: Binapura Aksara, 1997), 23

${ }_{25}$ Dikutip dari Kartini Kartono, Pemimpin Dan Kepemimpinan,.43-49.

${ }^{26}$ Al-Qur'ān, 22:41.

${ }^{27}$ Nur Effendi, Islamic Educational Leadership (Yogyakarta: Parama Publishing, 2015), 43. 
4. Ketegasan dalam pengambilan keputusan (Decisivines)

5. Kecerdasan (Intelligence)

6. Kepercayaan (Faith) ${ }^{28}$

Sementara itu Ki Hajar Dewantoro merumuskan tiga tingkah laku kepemimpinan yaitu: Ing ngarso sung Tulodo yang berarti pemimpin itu berada di depan, Ing Madyo Karso yang berarti bila pemimpin berada di tengah, ia membangkitkan tekad semangat dan Tut Wuri Handayani yang berarti pemimpin itu berada di belakang ia berperan kekuatan pendorong dan penggerak. ${ }^{29}$

Adapun Tokoh agama yang dimaksud dalam penelitian ini diantaranya kyai atau Ustadz yang ahli dibidang ilmu-ilmu agama Islam, tidak memimpin atau memiliki pesantren akan tetapi berperan besar dalam melakukan transformasi sosial terhadap masyarakat sekitar dan Tokoh agama hindu yang yang memiliki keunggulan dalam ilmu keagamaannya. Hal ini dapat diketahui sebagai berikut:

\begin{tabular}{|l|l|l|}
\hline No & \multicolumn{1}{|c|}{ Tokoh Agama Islam } & \multicolumn{1}{|c|}{ Tokoh Agama Hindu } \\
\hline 1 & Ustadz Amrullah & Pemangku Sugeng \\
\hline 2 & Ustadz Ridho & Pemangku Muncul \\
\hline 3 & Ustadz Sirath & Pemangku Mariono \\
\hline 4 & Ustadz Musta'in & \\
\hline
\end{tabular}

Tokoh Agama Islam adalah bernama Ustadz Amrullah berusia 34 Tahun. Beliau berasal dari Pasuruan dan sekarang menetap Di Dsn Dadapan bersama Istrinya dan dua anak kandungnya. Beliau ditokohkan oleh masyarakat semenjak menikah dengan istinya tersebut. Namun, tidak heran kalau ilmu pengetahuan beliau sudah tidak diragukan lagi. Beliau merupakan lulusan Sarjana Pendidikan Islam di Malang dan sekarang merupakan salah satu Guru di SMA 03 Lumajang. Selain itu beliau juga aktif menjadi guru TPQ di Musholla yang dimilikinya dan sebagai imam tetap, beliau juga aktif menjadi khutbah diberbagai masjid dan mengisi Majlis Talim. ${ }^{30}$

Peran penting para tokoh agama sangat dibutuhkan sebagai sarana media menguat keyakinan para penganut agama yang dianutnya. Peran tokoh agama setiap agama yang ada di Indonesia pada khususnya memiliki tanggung jawab besar dalam menguatkan ajarannya kepada umat. $^{31}$

Secara esensial paling tidak ada dua fungsi keagamaan yang cukup sentral dari tokoh agama yaitu:

\footnotetext{
${ }^{28}$ Dikutip dari Kartini Kartono, Pemimpin Dan Kepemimpinan,.43-49.

${ }^{29}$ Veithzal Rivai Zainal, Kepemimpinan dan Perilaku Organisasi (Jakarta: Raja Wali, 2017), 120.

30 Amrullah, Wawancara, Dadapan, 17 Pebruari 2018

31 Elly Irawan, Pengembangan Masyarakat (Jakarta: Universitas Terbuka, 1995), 34

68 | Tarbiyatuna: Jurnal Pendidikan Islam; Volume 13, Nomor 1, Februari 2020 p-ISSN: 2085-6539; e-ISSN: 2242-4579
} 
1) Fungsi pemeliharaan ajaran agama adalah bahwa tokoh agama memiliki hak dan wewenang untuk memimpin upacara-upacara keagamaan, di samping berfungsi sebagai penjaga kemurnian ajaran agamanya.

2) Fungsi pengembangan ajaran agama adalah bahwa mereka berupaya melakukan misi untuk menyiarkan ajaran agama dalam rangka meningkatkan kualitas dan kuantitas pemeluknya.

Berdasarkan dimensi tersebut Nawawi membedakan enam fungsi kepemimpinan: ${ }^{32}$

a) Fungsi Instruktif Yaitu seorang pemimpin harus memiliki kemampuandalam memberikan perintah yang bersifat kumunikatif, harus dimengerti oleh yang menerima perintah

b) Fungsi Konsultatif ialah seorang pemimpin perlu melakukankonsultasi dengan anggota atau masyarakat, baik secara terbatas maupun meluas sebelum suatu keputusan ditetapkan. Sebagai konsultan pemimpin harus menyimak berbagai persolan aspirasi, pendapat, perasaan, data, informasi yang disampaikan oleh masyarakat untuk mendapatkan umpan balik (Feed Back) dalam rangka menyempurnakan keputusan yang diambil jika itu diperlukan.

c) Fungsi Partisipasi adalah seorang pemimpin harus berusaha mengaktifkan setiap anggotanya, sehingga selalu terdorong melakukan untuk melakukan komunikasi yang menjadi peluang terjadinya pertukaran informasi, pendapat, gagasan dan lain-lain

d) Fungsi Delegasi adalah setiap pemimpin tidak mungkin dapat bekerja sendiri, untuk itu harus bersedia dan mampu mendelegasikan sebagaian wewenangnya kepada anggota. Seorang pemimpin harus mampu memberi kepercayaan, sedangkan penerima delegasi harus mampu memelihara kepercayaan.

e) Fungsi Pengendalian adalah dalam kehidupan masyarakat fungsi tokoh agama dapat dilakukan dengan memberikan bimbingan kepada umat beragama dalam berinteraksi dengan umat lainnya

f) Fungsi Keteladanan adalah Setiap pemimpin dituntut agar selalu memberikan contoh yang baik, berperilkau yang sopan sesuai dengan norma-norma yang berlaku di lingkungan organisasi atau masyarakat. ${ }^{33}$

Peranan tokoh agama yaitu sebagai pemimpin yang berfungsi dan bertanggungjawab atas berbagai kegiatan keagamaan dalam pengertian sempit yang mengurus kegiatan ibadah sehari-hari seperti penyuluhan agama, memimpin upacara ritual keagamaan (menjadi imam masjid, khotib, pembaca doa, menikahkan, mengurusi peringatan hari besar Islam, mengajar ngaji, kegiatan keagamaan) dan juga sebagai pengambil keputusan paling dominan dalam masyarakat. ${ }^{34}$

\footnotetext{
32 Veithzal Rivai Zainal, Kepemimpinan dan Perilaku,. 34-35.

${ }^{33}$ Hadari Nawawi, Kepemimpinan menurut Islam (Gajah Mada University Press, Yogyakarta, 1993), 143-152.

34 Choirul Fuad Yusuf, Peran Agama Terbadap Masyarakat Studi Awal Proses Sekularisasi Pada Masyarakat Muslim Kelas Menengah (Jakarta : Badan Litbang Agama Dan Diklat Keagamaan, 2001), 100.
} 
Selanjutnya ada beberapa peran tokoh agama yang begitu sentral dalam menggerakkan masyarakat: ${ }^{35}$

1. Sebagai penyuluh masyarakat yang memberi jalan penerangan bagi masyarakat agar bisa berkehidupan yang lebih baik sesuai dengan ajaran yang dibuat pedoman.

2. Sebagai pemimpin dapat menjadi panutan dan teladan bagi masyarakat, sehingga masyarakat tergerak untuk mengikuti arahan serta ajakannya.

3. Sebagai fasilitator yang dapat menjembatani perubahan dan memberikan informasi yang terbaru mengenai hal agama, sosial, ekonomi, dan sebagainya.

4. Sebagai motivator, tokoh agama bisa berperan membangkitkan masyarakat untuk memberikan pemahaman-pemahaman agama.

Peranan tokoh agama yaitu sebagai pemimpin yang berfungsi dan bertanggungjawab atas berbagai kegiatan keagamaan dalam pengertian sempit yang mengurus kegiatan ibadah sehari-hari seperti penyuluhan agama, memimpin upacara ritual keagamaan (menjadi imam masjid, khotib, pembaca doa, menikahkan, mengurusi peringatan hari besar Islam, mengajar ngaji, kegiatan keagamaan) dan juga sebagai pengambil keputusan paling dominan dalam masyarakat. ${ }^{36}$

Peran tokoh agama dalam pendidikan toleransi beragama sangatlah vital, karena kerukunan dan keharmonisan masyarakat ada ditangan tokoh agama selaku panutan dalam segala aspek. Tokoh-tokoh dalam pendidikan toleransi beragama selalu berupaya dalam menciptakan pendidikan toleransi di Desa Kertosari. Dengan sifat yang dimiliki ketokohan yang terdapat di Desa Kertosari sangatlah disegani oleh masyarakat bahkan menjadikan sebagai rujukan dalam memecahkan problematika kehidupan beragama. Pernyataan ini semakin dikuatkan dengan pendapat Ramlan Surbakti bahwa tokoh agama ialah seseorang yang disegani dan dihormati secara luas oleh masyarakat dan dapat menjadi faktor yang menyatukan suatu bangsa dan negara. ${ }^{37}$

Secara umum keberadaan para Ustadz dan pemangku di Dsn. Dadapan dipandang sebagai pemimpin infomal, sebagaimana yang dijelaskan oleh Kartini Kartono bahwa ciri-ciri pemimpin informal ialah Status kepemimpinannya berlangsung selama kelompok yang bersangkutan masih mau mengakui dan menerima pribadinya. ${ }^{38} \mathrm{Hal}$ ini dapat dibuktikan dengan tidak mempengaruhi terhadap masyarakat dalam mempercayai akan keunggulan baik secara moral maupun kealiman yang dimiliki. Pengaruh inilah yang sepenuhnya ditentukan oleh kekharismaan mereka dalam

\footnotetext{
${ }^{35}$ Elli M. Stiadi, Pengantar Sosiologi, (Jakarta: Bumi Aksara, 2001), 34.

${ }^{36}$ Choirul Fuad Yusuf, Peran Agama Terhadap Masyarakat Studi Awal Proses Sekularisasi Pada Masyarakat Muslim Kelas Menengah (Jakarta : Badan Litbang Agama Dan Diklat Keagamaan, 2001), 100.

${ }^{37}$ Ramlan Surbakti, Memahami Ilmu Politik (Jakarta:PT.Grasindo,1992), 15.

${ }^{38}$ Kartini Kartono, Pemimpin Dan Kepemimpinan, Apakab Pemimpin Abnormal Itu? Edisi baru (Jakarta: Raja Grafindo Persada, 1998), 10 .

70 | Tarbiyatuna: Jurnal Pendidikan Islam; Volume 13, Nomor 1, Februari 2020 p-ISSN: 2085-6539; e-ISSN: 2242-4579
} 
menjalankan tugas dan fungsinya sebagai peran tokoh agama. Bahkan realita yang terdapat di Dusun Dadapan masyarakat lebih tunduk terhadap tokoh agama dari pada umara'nya.

Tokoh agama merupakan gelar yang diberikan kepada Ustadz Amrullah, Ustadz Ridho, Ustadz Musta'in dan Ustadz Sirath dan pemangku Mariono, Sugeng, dan Muncul. mereka memiliki tanggungjawab dalam membimbing masyarakat untuk bisa memahami agama dengan benar. Menurut Choirul Fuad Yusuf peran tokoh agama ialah sebagai pemimpin yang berfungsi dan bertanggungjawab atas berbagai kegiatan keagamaan ibadah sehari-hari. ${ }^{39} \mathrm{~T}$ okoh agama di Dusun Dadapan Desa kertosari menjalankan perannya sebagai pemimpin ia berhak untuk mengatatur, membimbing, dan memberi petunjuk. Keseharian dari tingkah laku dan sikap juga menjadi contoh bagi masyarakat. sebagai tokoh agama tugasnya yaitu menjadi imam shalat adalah kewajiban pada setiap tokoh agama.

Peran tokoh agama di Desa Kertosari Dusun Dadapan dapat diklasifikasikan sebagai berikut:

1. Sebagai pemimpin. Yaitu Seorang tokoh agama dengan pengetahuan dan karisma yang dimilikinya mampu memberikan dorongan-dorongan spiritual dan sosial dalam kehidupan manusia, sekaligus menjadi pihak penengah dalam menyelesaikan masalah-masalah yang bersangkutan dengan konflik antarumat beragama.

Menurut Ustd. Ridho peran Tokoh Agama dalam pendidikan toleransi sebagai pemimpin umat Islam, karena di Desa Kertosari Masyarakat lebih tunduk terhadap Pemimpin Agama dari pada pemerintahannya. Karena, masyarakat menganggap bahwa adanya tokoh agama sangat dibutuhkan di tengah dalam mewujudkan kerukunan antarumat beragama khususnya dalam mengarahkan ajaran yang telah dianut oleh masyarakat

2. Sebagai Motivator, tokoh agama Islam dan Hindu harus memiliki strategi dalam menanamkan toleransi antarumat beragama supaya masyarakat tetap berupaya menanamkan sikap toleransi. Dalam menjalankan peran tersebut Tokoh Agama di Dusun Dadapan Desa Kertosari memotivasi masyarakat dengan memberikan nasehat-nasehat yang menganjurkan masyarakat untuk menjaga tali persaudaraan dengan mengisi beberapa kegiatan keagamaan seperti membaca khutbah dengan tema yang bersangkutan dengan menjunjung nilai toleransi beragama.

Dalam menjalankan fungsinya sebagai pemimpin tokoh agama selalu menekankan kepada warganya bahwa walau beda agama, mereka juga orang sendiri, artinya masyarakat Dsn Dadapan adalah satu darah dan satu keturunan dari nenek moyang mereka. Selain itu, selalu berusaha menjadi tokoh agama yang baik sehingga dijadikan panutan oleh masyarakat Desa

${ }^{39}$ Choirul Fuad Yusuf, Peran Agama Terbadap Masyarakat Studi Awal Proses Sekularisasi Pada Masyarakat Muslim Kelas Menengah (Jakarta : Badan Litbang Agama Dan Diklat Keagamaan, 2001), 100. 
Kertosari dalam membina dan menghargai perbedaan antarumat beragama dalam kehidupan yang berdampingan tersebut

3. Sebagai Penyuluh. Dalam perannya Tokoh Agama Hindu ialah sebagai penyuluh dengan menyampaikan ajaran toleransi dalam kegiatan keagamaan yaitu dalam acara Persemuan, Darma Santi, Pio Dalan, Hari Raya Hindu dan Pujawali Karma.

4. Sebagai Panutan. Tokoh Agama di Desa Kertosari sangatlah dikagumi sikap yang dimiliki. Dengan sikap dan sifat tersebut maka masyarakat menjadikan para Tokoh Agama sebagai panutan dalam segala hal yang bersangkutan dengan ajaran agama baik dalam memutuskan suatu keputusan, menjadikan sebagai cerminan dan menjadikan sebagai tokoh yang harus disegani dalam kehidupan bermasyarakat.

5. Sebagai Pembimbing. Berdasarkan hasil observasi, peran dari Tokoh Agama di Desa Kertosari ialah sebagai pembimbing. Hal ini dapat digambarkan dengan kebiasaan para Tokoh agama yang membimbing, membina dan mengajarkan ajaran-ajaran yang dianutnya.

Gambaran tersebut dapat diketahui ketahui umat Islam melakukan ibadah sholat wajib 5 Waktu yaitu dengan menjadi imam dan mengarahkan warga dalam membimbing tata cara dalam pelaksanaan tersebut khususnya bagi umat yang baru masuk Islam (Mualllaf), kemudian beliau juga mengajar anak-anak kecil mengaji di Sore harinya hal ini merupakan tugas belaiu dalam mentransfer ilmu.

Sementara itu, Tokoh Agama juga membimbing dalam penanaman sikap toleransi pada masyarakat Dusun Dadapan dengan mengisi tausiyah setelah Sholat Maghrib dilaksanakan. Di kultum ini beliau selalu memberikan wacana tentang arti penting menanamkan pendidikan toleransi antarumat beragama supaya dapat berhubungan dengan baik.

6. Sebagai Pendidik. Tokoh Agama Islam dalam melaksanakan tugasnya menjadi imam dalam sholat berjamaah, menjadi khotib dan memimpin doa dalam acara-acara keagamaan yang dilaksanakan di Desa Kertosari seperti slametan nyewu, tahlilan, walimah khitan dan urusy dan aktif juga dalam kegiatan-kegiatan lainnya yang diselenggarakan di Masjid.

Selain itu, sebagai pendidik tokoh agama di Dsn Dadapan juga mengajarkan ajaranajaran dalam agama yang dianutnya seperti Ustadz Musta'in setiap sore mengajar ngaji Alquran, Ustadz Amrullah juga mengajar TPQ di Desa Dadapan. Pemangku Sugeng juga mengajarkan amalan-amalan yang terdapat dalam ajarannya di pertemuan pesamuan.

Misi utama sebagai Tokoh Agama Islam didunia adalah berdakwa. Dalam misi tersebut para tokoh agama menyebarkan agama Islam dengan cara yang santun dan menjunjung tinggi nilai agama Islam, membuat masyarakat Desa Kertosari berantusias mengikuti kegiatan-kegiatan keagamaan seperti Albanjari, Muslimatan, Takbir Keliling yang digelar tiap tahun dan kegiatan 
lainnya. Melalui kegiatan kesenian tersebut ternyata dapat menarik perhatian umat Hindu dalam mengetahui ajaran Islam secara mendalam. Hal ini dapat diketahui dalam presentase penduduk Umat Hindu yang tiap Tahun semakin berkurang. Bapak Wiro sebagai Kepala Desa menjelaskan bahwa Jumlah Umat Hindu ketika saya menjabat sebagai Kepala Desa mencapai 77 KK dan sekarang sudah menjadi $14 \mathrm{KK}$. Hal ini menjadi telah menjadi wujud upaya Kepala Desa dalam menyebarkan agama Islam di penjuru Dunia, dan hal ini tidak lepas dari peran Tokoh Agama Islam yang selama ini telah berupaya berdakwa dengan baik karena berdasarkan pernyataan masyarakat yang baru masuk Islam ia mengatakan alasannya bahwa Islam selalu memberikan makna kedamaian dalam kehidupannya.

Hasil dari analisis tersebut dapat dikaitkan dengan pendapat Elli M. Setiadi dalam bukunya yang berjudul Pengantar Sosiologi. Dalam penjelasannya peran seorang tokoh agama dalam menggerakkan masyarakat sangatlah sentral. ${ }^{40}$ Jika dikaitkan dengan hasil analisis diatas maka peran tersebut dibagi menjadi:

1. Sebagai Pemimpin yaitu menjadi panutan dan teladan bagi masyarakat sehingga masyarakat tergerak mengikuti arahannya. Dalam konteks tersebut masyarakat Dusun Dadapan sangatlah tunduk terhadap kepemimpinan seorang Tokoh Agama masing-masing. Hal ini dapat dilihat dari sifat yang dimiliki oleh seorang pemimpin yaitu mengayomi kepada mayarakat sehigga masyarakat di Dsn Dadapan jika menghadapi problematika kehidupan tidak sungkan-sungkan untuk minta bantuan kepada Tokoh Agama.

2. Sebagai Motivator tokoh agama harus membangkitkan masyarakat untuk memberikan pemahaman-pemahaman agama. Upaya yang dilakukan oleh Tokoh agama di Dsn Dadapan dalam pendidikan toleransi tergambar disaat memberikan motivasi dengan cara membuat kegiatan-kegiatan keagamaan (Majelis ta'lim, cermah/tausiah, yasiinan, khotmil Al-Quran, Takbir Keliling dan hadrah Al-Banjari).

3. Sebagai penyuluh. Peran tokoh agama sebagai penyuluh yang dipaparkan oleh Stiadi harus memberikan jalan kepada masyarakat maka teori tersebut berkaitan dengan peristiwa yang terjadi pada tokoh agama di Desa Kertosari yaitu dengan cara berkomunikasi dalam bentuk menyampaikan informasi terbaru pada masyarakat. Informasi ini disampaikan dalam bentuk yang beragam seperti musyawarah, pengumuman. kegiatan tersebut beertujuan meningkatkan pemahaman agama pada masyarakat.

Peran yang dijalankan oleh Tokoh Agama mempunyai gaya dan metode tersendiri dalam menenamkan pendidikan toleransi. Dalam menerapkan peran tersebut Tokoh agama Di Dusun Dadapan Desa Kertosari lebih ke peran sebagai pendidik, sebagai panutan, sebagai penyuluh dan

${ }^{40}$ Elli M. Stiadi, Pengantar Sosiologi (Jakarta: Bumi Aksara, 2001), 34. 
sebagai motivator artinya dalam pendidikan toleransi beragama peran yang dianggap penting ialah peran-peran tersebut.

Sedangkan dalam artikel ini, penulis sebagai peneliti menemukan dalam analisisnya bahwa peran tokoh agama di Desa Kertosari terdiri dari sebagai pemimpin, sebagai motivator, sebagai penyuluh, sebagai panutan, sebagai pembimbing dan sebagai pendidik. Maka dapat disimpulkan bahwa penemuan yang ditemukan dalam peran tokoh agama tentang pendidikan toleransi umat beragama di Dusun Dadapan Desa Kertosari Kabupaten Lumajang ialah peran sebagai panutan, sebagai pembimbing, dan sebagai pendidik. Selain peran tersebut telah sesuai berdasarkan teori yang ada.

\section{Kesimpulan}

Konsepsi Tokoh Agama dalam memaknai pendidikan Toleransi beragama ialah sikap saling menghargai, sikap saling menerima perbedaan dengan memperhatikan batasan-batasan tertentu berdasarkan Kitab suci Al-Qur'an dan Hadist sedangkan umat Hindu ialah Kitab suci Weda dalam kajian Teposeliro. Bentuk toleransi tersebut terdiri dari Kegiatan Keagaamaan Kegiatan Sosial meliputi: dan Kegiatan Ekonomi. Adapun peran sentral Tokoh Agama dalam pendidikan toleransi beragama di Dusun Dadapan Desa Kertosari Kecamatan Pasrujambe ialah sebagai pemimpin, sebagai motivator, sebagai panutan, sebagai penyuluh, sebagai pendidik dan sebagai pembimbing.

\section{Referensi}

Abdullah, Maskuri. 2001. Pluralisme Agama dan Kerukunan dalam Keagamaan. Jakarta: Penerbit Buku Kompas.

Abdusshomad, Muhyiddin. 2015. Hujjab NU Aqidah, Amaliah, Tradisi. Surabaya: Kahlista.

Ali dan Mohammad Daud. 1986. Islam Untuk Disiplin Ilmu Hukum, Sosial dan Politik. Jakarta: CV Wirabuana.

Ali, Muhammad. 1997. Kamus lengkap bahasa Indonesia modern. Cet I. Jakarta: Pustaka Amani. Al-Munawar, Said Agil Husin. 1995. Fikih Hubungan Antaragama. Jakarta: Ciputat Press.

Al-wa'iy, Taufik. 2010. Dakwah Kejalan Allah; muatan, sarana dan tujuan. Jakarta: Robbani Press. As Saidi, Abd. Al Mu’tal. 1999. Kebebasan Berfikir dalam Islam. Yogyakarta: Adi Wacana.

Burhanuddin, Daya. 2004. Agama Dialogis Merenda Dialektika Idealitas dan Realita Hubungan antar-Agama Mataram-Minang Lintas Budaya. Yogyakarta: t.tp.

Chalik, Abdul dan Ali Hasan Siswanto. 2013. Pengantar Studi Islam. Surabaya: Kopertais IV Press.

Effendi, Nur. 2015. Islamic Educational Leadership. Yogyakarta: Parama Publishing.

Fatkhurroman, Amang. 2006. Menjaga Kearifan Budaya Metodelogi Pendekatan Penyelesaian Konflik Budaya. Pasuruan: Universitas Yudharta. 
Hidayati, Tri Wahyu. 2008. Apakah Kebebasan Beragama Sama Dengan Bebas Pindah Agama?. Surabaya: STAINSALATIGAPRESS.

Husna, Khotimatul. 2006. 40 Hadits Shabih Pedoman Membangun Toleransi. Yogyakarta: Pustaka Pesantren.

Irawan, Elly. 1995. Pengembangan Masyarakat. Jakarta: Universitas Terbuka.

Ismail, Faisal. 2017. Islam Yang Produktif. Yogyakarta: IRCiSoD.

Kamisa. 1997. Kamus Lengkap Babasa Indonesia. Surabaya:Kartika.

Kartono, Kartini. 1998. Pemimpin Dan Kepemimpinan, Apakah Pemimpin Abnormal Itu? Edisi baru. Jakarta: Raja Grafindo Persada.

Luth, Thohir,. 2007. Pendidikan Agama Islam (Malang: Pusat Pembinaan Agama (PPA).

Munawir, Ahmad Warson. T.t. Kamus Arab Indonesia al-Munawir. Yogyakarta: Balai Pustaka Progresif.

Musahadi. 2007. Mediasi Dan Resolusi Konflik di Indonesia. Semarang: Walisongo: Mediation Centre.

Naim, Ngainun dan Achmad Sauqi. 2008. Pendidikan Multikultural: Konsep dan Aplikasi. Yogyakarta: Ar-Ruzz Media.

Nawawi, Hadari. 1993. Kepemimpinan menurut Islam. Gajah Mada University Press, Yogyakarta.

Nazir, Mohammad. 2005. Metode Penelitian. Bogor: Ghalia Indonesia.

Ronald. 2004. Tokoh Agama Dalam Masyarakat . Jakarta : Rineka Cipta.

Ruslani. 2000. Masyarakat Dialoq Antar Agama, Studi atas Pemikiran Muhammad Arkoun. Yogyakarta:Yayasan Bintang Budaya.

Roqib, Mohammad. 2009. Imu Pendidikan Islam. Yokyakarta: LkiS.

Sanjaya, Julius. 1997. Ciri-Ciri Pemimpin Yang Berprinsip: Principle Centered Leadership. Jakarta: Binapura Aksara.

Sahilun dan Hafi Anshari. 1982. Pokok-Pokok Pendidikan Agama Islam di PeryuruanTinggi. Surabaya: Al-Ikhlas.

Soekanto, Soerjono. 1990. Sosiologi Suatu Pengantar. Jakarta: Rajawali Pers.

Stiadi, Elli M. 2001. Pengantar Sosiologi. Jakarta : Bumi Aksara.

Surbakti, Ramlan. 1992. Memahami Ilmu Politik. Jakarta:PT.Grasindo.

Thoha, Miftah. 2002. Pembinaan Organisasi:proses diagnosa dan intervensi. Jakarta: Raja Grafindo Persada.

Tim Prima Pena, 2010. Kamus Besar Bahasa Indonesia. t.tp: Gita Media Press.

Yusuf, Choirul Fuad. 2001. Peran Agama Terhadap Masyarakat Studi Awal Proses Sekularisasi Pada Masyarakat Muslim Kelas Menengah. Jakarta : Badan Litbang Agama Dan Diklat Keagamaan.

Zainuddin. 2013. Pluralisme Agama dalam Analisis Konstruksi Sosial: Pergulatan Dialogis Islam-Kristen di Indonesia. Malang: UIN-Maliki Press.

Zainal, Veithzal Rivai. 2017. Kepemimpinan dan Perilaku Organisasi. Jakarta: Raja Wali.

Al-Qur'ān, 109: 1-6; 16:125; 2:190; 49:13; 5:2; 60:8-9; 2:256; 88:21-22; 53:23.

http://kertosari-pasrujambe.lumajangkab.go.id/index.php/first/katagori/40 